Research Report No. 44/2013

\title{
A Context of Justice: Ontario's Justices of the Peace - From the Mewett Report to the Present
}

Jamie Cameron

Osgoode Hall Law School of York University, jcameron@osgoode.yorku.ca

Follow this and additional works at: http://digitalcommons.osgoode.yorku.ca/clpe

\section{Recommended Citation}

Cameron, Jamie, "A Context of Justice: Ontario's Justices of the Peace - From the Mewett Report to the Present" (2013). Comparative Research in Law \& Political Economy. Research Paper No. 44/2013.

http://digitalcommons.osgoode.yorku.ca/clpe/286 


\section{OSGOODE}

OSGOODE HALL LAW SCHOOL

YOR K UNIVERSITY

\section{OSGOODE HALL LAW SCHOOL}

Comparative Research in Law \& Political Economy

RESEARCH PAPER SERIES

Research Paper No. 44/2013

\section{A Context of Justice: Ontario's Justices of the Peace - From the Mewett Report to the Present}

Jamie Cameron

Editors:

Peer Zumbansen (Osgoode Hall Law School, Toronto, Director Comparative Research in Law and Political Economy)

John W. Cioffi (University of California at Riverside)

Comparative Research in Law \& Political Economy 


\title{
A Context of Justice: \\ Ontario's Justices of the Peace - From the Mewett Report to the Present
}

\author{
Professor Jamie Cameron \\ Osgoode Hall Law School \\ October 10, 2013
}




\section{The past 100 years or so}

There is little reluctance to acknowledge the role justices of the peace play in the justice system; to the contrary, the vital functions the justices perform are routinely and unfailingly recognized. ${ }^{1}$ That said, there is a difference between acknowledging the importance of the office, and understanding what it is. Thirty some years ago, Alan Mewett reported that "the duties and functions of the Justice of the Peace are not always clearly understood by those in the criminal justice system", and added that he was not sure "all Justices of the Peace understand their own duties and functions”. ${ }^{2}$

At the time, Mewett attributed this lack of understanding to the "failure to commit enough financial resources to the office of the Justice of the Peace”. ${ }^{3}$ In 1981, he remarked that in the last one hundred years or so the "prestige and visibility of the Justice of the Peace in the community has slowly been whittled away". ${ }^{4}$ Paradoxically, he found that even as their role was being downplayed, new responsibilities were being imposed on the justices. ${ }^{5}$ Not only was their corner of the system disorganized and chaotic, they were set apart from other judicial actors in their status and roles as lay justices.

\footnotetext{
*Professor, Osgoode Hall Law School. A short bio is attached to the paper as an appendix. I would like to thank Justice Gerry Manno, Justice of the Peace and Osgoode Hall PhD candidate, and James C. Morton, for reading an earlier draft of this paper. I also thank Robert Karass, Osgoode Hall J.D. 2013, for his assistance, and Kendall Grant, J.D. Osgoode Hall 2015, for his research assistance in the preparation of this paper.

${ }^{1}$ See, e.g., Ell v. Alberta, [2003] 1 S.C.R. 857 at para. 5 (stating that justices of the peace, in many provinces, "have come to occupy a critical role as the point of entry into the criminal justice system"); and Report of the Fourth Ontario Justices of the Peace Remuneration Commission, 2007 (the "Cory Commission") at 4 (stating that "perhaps insufficient attention" has been given to the work of Ontario justices of the peace in the past) and 6 (making remarks, not in criticism of earlier Commissions but "simply as a present day recognition and confirmation of the exceedingly important work performed by Justices of the Peace").

${ }^{2}$ Alan w. Mewett, Report to the Attorney General of Ontario on the Office and Function of Justices of the Peace in Ontario (the "Mewett report")(1981), at 38.

${ }^{3}$ Ibid.

${ }^{4}$ Ibid. at 55.

${ }^{5}$ lbid. at 38.
} 
By then, it had become evident that the need for change was compelling. Major reports on the administration of justice in Ontario by the McRuer Commission and Ontario Law Reform Commission (OLRC) stated the case for reform and laid the foundation for Professor Mewett, whose terms of reference were exclusive to the office and function of Ontario's justices of the peace. $^{6}$ In due course, statutory reforms would be undertaken and the systemic problems corrected, with the result that today's office bears little resemblance to the office of the past.

This short paper has been written at the request of the Association of Justices of the Peace of Ontario (AJPO), in preparation for the work of the Sixth Remuneration Commission, and its purpose is to provide a context for that discussion. ${ }^{7}$ It begins by observing that to situate Ontario’s justices of the peace today, it is necessary to retrace the history from 1981 to the present. Accordingly, the next section explains how the office was remodelled in the years after the Mewett report, and what is significant about those reforms. In brief, the key point is that a statutory framework that comprehensively addresses the governance of the office is now in place. Not only do the structures established by this framework protect the independence and professionalism of the justices, in doing so the statutory reforms took critical steps to bring justices of the peace into closer alignment with other judicial officers in the province. This narrative is significant because it is only by recalling the state of affairs in 1981 that the transformative consequences of those reforms can truly be understood.

\footnotetext{
${ }^{6}$ Ontario Royal Commission Inquiry into Civil Rights (the "McRuer Commission")(1968), chapter 38; Report on the Administration of Ontario Courts, Ontario Law Reform Commission ("OLRC report") (1973).

${ }^{7}$ In requesting a paper, the AJPO was clear that I should provide an update on the Mewett report that is academic in nature. In the interest of readability it omits citations to the many statutes and statutory provisions referred to, and also relies on website citations for reports and other materials that are accessible online.
} 
The structures and appointments of office are an important part of the evolution of Ontario's justices of the peace, but do not tell the whole story. In addition, the office needs to be placed in the context of a system of justice that is complex, seamless, and highly interdependent. All parts of the system are vital, and must function as smoothly as possible. From that perspective, it is important to consider what justices of the peace do, and how that work has changed over the years. A review of that work and the functions they serve confirms that Ontario’s justices are a vital, indispensable, and integral part of the justice system.

A further observation is that a remaining difference between justices of the peace and other members of the judiciary is their status, to this day, as lay justices. ${ }^{8}$ This is not the time or place to consider whether the office is an anomaly, or holdover from a bygone time before law was professionalized. The respective merits of a professional or lay bench of justices of the peace raise pivotal questions about policy and the design of justice. ${ }^{9}$ Though this paper does not directly engage that question and its implications for remuneration, two comments can be made. The first is that access to justice is an overarching goal of the system, and that aspiration is shared by and sought after as much by justices of the peace as by others. Yet this value cannot be maximized unless it infuses all parts, and that requires resources to be spread fairly throughout

\footnotetext{
${ }^{8}$ That, too, is changing. Although it is not a requirement, a recent figure indicates that $10 \%$ of Ontario's justices are legally trained; supra note 49 . Anecdotal information suggests that the number is higher than that and might now be in the range of $14-15 \%$.

${ }^{9}$ See Bill 97, the Ontario Justices of the Peace Modernization Act, 2012, a private member's bill introduced by MPP David Orazietti, which proposed a return to two classes for justices of the peace - presiding and administrative and introduced a requirement that those appointed as presiding have a law degree and five years' experience as practising lawyers. Bill 97 was one of 104 bills in process when the provincial legislature was prorogued on October 23, 2012. http://www.ontla.on.ca/web/bills/bills detail.do?locale=en\&Intranet=\&BillID=2645
} 
the system. More to the point, it is a reminder that justices of the peace should be integrated into the rest of the system, and not set apart because of the unique history and evolution of the office. The second accepts the difference in training between the justices and others, but cautions that its significance can be overstated. Reforms to the office of Ontario justices of the peace have closed the gaps on independence and professionalism that were glaring at the time of the Mewett report. Though remaining differences should not be discounted, justices of the peace today are more like other members of the judiciary than ever before.

\section{Transforming the justices: from 1981 to the present}

\section{$\underline{\text { Urgent need }}$}

There could be no doubt whatsoever that the system for justices of the peace was in dire need of reform. Years before the Mewett report was written, it had been harshly criticized by the McRuer Commission, which dealt "emphatically” with the issues. In 1968, the McRuer report noted that there were more than 500 justices of the peace who should never have been appointed, and recommended that all existing appointments be cancelled and a "fresh start" made. ${ }^{10}$ The Commission also dismissed the role justices play in safeguarding the civil liberties of individuals as "little more than a sham". 11

Five years later, the OLRC’s Report on the Administration of Ontario Courts complained that the exact number of justices in Ontario was unknown, and referred to an indeterminate group of appointees, "whose names are not officially recorded anywhere”. ${ }^{12}$ The report also observed

\footnotetext{
${ }^{10}$ Cited in OLRC report, volume 2, supra note 6, at 17.

${ }^{11}$ McRuer report, supra note 6, at 524 (cited in Ell v. Alberta, supra note 1, at para. 6).

${ }^{12}$ OLRC report, supra note 6, at 17.
} 
that Ontario justices of the peace do not operate "within an organized framework" and emphasized the "urgent need to establish some order and organization for the office". ${ }^{13}$ The Commission used the language of "urgent need" a second time in calling for clarification of the relationship between the JPs, and the provincial judges and their court system. ${ }^{14}$

Unlike the McRuer and OLRC reports, which examined Ontario courts, Professor Mewett's landmark study focused exclusively on JPs and their part in the justice system. On issue after issue relating to the structure and organization of the office, terms and conditions of appointment, and workplace conditions, he called repeated attention to profound and ongoing systemic problems. In doing so, he openly expressed anger and frustration about the state of affairs and low status of Ontario's justices of the peace. The Mewett report is in fact a chronicle of neglect, which demonstrates how a vital part of the justice system was simply let go and left to flounder, without structure, guidance, or resources. This theme of neglect surfaced again ten years later, in a study of Canada's justices of the peace headed up by Professor Doob. Understanding Justices concluded, in more general terms, that many of the problems surrounding justices of the peace in Canada "derive from their generally poor treatment by the provinces". 15

What follows are some of the Mewett report's highlights and key findings. When the report was written, Ontario’s justices of the peace were an ad hoc mix of full-time, part-time and fee for service appointments, with little or no organization or to hold the system together or show

\footnotetext{
13 Ibid. at 16 (emphasis added).

14 Ibid.

${ }^{15}$ A. Doob, P. Baranek, and S. Addario, Understanding Justices: A Study of Canadian Justices of the Peace (the "Doob Report"), University of Toronto Centre of Criminology, 1991, at 250.
} 
how it worked. On the issue of appointments, Mewett stated that "exactly what is meant by 'qualifications' is a matter of some doubt because no one has ever actually tried to articulate precisely what is meant by being qualified to be a Justice of the Peace". ${ }^{16}$ Meanwhile, it was widely perceived at the time that appointments had little to do with merit, and were more likely a form of favouritism or reward. ${ }^{17}$ Ten years later, and more than twenty years after the McRuer Commission complained that there was no list of Ontario justices, the Doob report would reveal that the Attorney General's office “freely admitted that not only do they not have an accessible list of justices of the peace, but they do not know who is a justice”. ${ }^{18}$

Meanwhile, Mewett also discovered that the organization of work was profoundly flawed. Who did what was governed by a system of "directions", which classified justices of the peace into one of five designations which then both determined and limited the assignment of work. ${ }^{19}$ Where justices sat and what kinds of assignments they drew depended on "directions" that were hierarchical in nature, were treated as a badge of prestige, and were often granted, as a result, “as a kind of reward”. ${ }^{20}$ In Mewett's words, the "'classification' of the Justices of the Peace [was] chaotic", and he described the system as "hopelessly confused and unnecessarily complex". ${ }^{21}$ It was hardly a surprise, in these circumstances, that workloads were irregular and uneven. That problem was re-inforced, if not systemically ingrained, by the remuneration practices of the day.

\footnotetext{
${ }^{16}$ Mewett Report, supra note 2, at 67.

${ }^{17}$ Doob report, supra note 15 , at 19.

${ }^{18} \mathrm{Ibid}$. at 19. According to the report, the Attorney General's office began assembling a list in 1988.

${ }^{19}$ Mewett report, supra note 2, at 10 (describing the five types of directions then in existence).

${ }^{20}$ Ibid.at 17.

${ }^{21}$ Ibid. at 14.
} 
The various methods and levels of remuneration were dysfunctional, not to mention deeply unfair. Mewett declared it impossible to provide "any precise picture of the general level of remuneration,”22 and was deeply disturbed by the persistence of fee for service arrangements, which he described as "utterly intolerable" and a reflection of the "complete ignorance of the proper function and authority of the Justice of the Peace". ${ }^{23}$ He fumed that "this was nothing more nor less than an invitation to a Justice of the Peace to abdicate his responsibility." ${ }^{24}$ As he explained, "[t]he outrageous result is that some Justices are perceived both by the police and the public as police Justices of the Peace while others pay for their rectitude by receiving little in the way of fees”. 25

Regrettably, Ontario's justices of the peace were not at all independent but were left, instead, to fend for themselves without administrative structures, resources, or modest forms of support. In a system in which they were virtually unknown, few justices were removed, though tenure of office was insecure and the process then in place to deal with matters of competence and removal was inadequate. In Mewett's view, the Justices of the Peace Review Council fell short of providing safeguards because "[s]ecurity, to be meaningful, must embrace not only proper procedures to prevent the arbitrary revocation of the Commission ... but also safeguards

\footnotetext{
${ }^{22}$ Ibid. at 20.

${ }^{23} \mathrm{lbid}$. at 23.

${ }^{24}$ Ibid. at 23.

${ }^{25}$ Ibid.
} 
against arbitrary administrative maneuvers". ${ }^{26}$ He identified security of tenure as a critical element of independence and wrote strongly of the need for this to be addressed. ${ }^{27}$

At this point in time, the justices were still closely associated with the police and entangled with law enforcement by the fee for service arrangement, as well as by physical proximity. In the absence of court and office space, the default place of business for justices of the peace was all too often the local police station. ${ }^{28}$ Reliance on others for advice - whether Crown lawyers, provincial court judges, or the police - posed another serious threat to their independence. ${ }^{29}$ Yet, as Mewett pointed out, the need for advice was unavoidable because arrangements for the training and education of the justices were completely inadequate.

This pointed to another systemic problem, which was that little had been done to develop, promote or protect the professionalism of Ontario's justices. Mewett reported that access to education, training, and independent sources of advice ranged at the time from the "virtually non-existent to the barely acceptable, depending upon the location.” ${ }^{30}$ The working conditions of justices of the peace were also appalling: the justices lacked the minimal court and office space needed to discharge their responsibilities, and otherwise had almost no amenities. As Mewett

\footnotetext{
${ }^{26}$ Ibid. at 32.

${ }^{27}$ lbid. at 56 (stating that "[h]e should enjoy independence in his decision-making functions, free from pressure or interference and thus must enjoy some measure of security in his office, subject to being dismissed only for cause and only after due process").

${ }^{28} \mathrm{Ibid}$. at 33. As he put it, "the one location where a Justice of the Peace should not have office facilities is in a police station," and added that "[i]t is hardly worth belabouring such an obvious point save to say that this is highly improper".

${ }^{29}$ Mewett found it especially objectionable that the justices at times took advice from the police. As he explained, "[j]ustice is not done nor can it be seen to be done unless the independence of the Justice of the Peace is maintained by an arm's length relationship with the police," and added that "it is grossly improper for any police officer to offer unsolicited advice to a Justice of the Peace". Ibid. at 27.

${ }^{30}$ lbid. at 19.
} 
once again lamented, "[t]he reason is that no one has objectively decided precisely what the needs of the Justices of the Peace are”. ${ }^{31}$

Though the remark was made in a different context, it would have been just as apt to describe this as "[t]he old system of amateurish JPs." ${ }^{32}$ Having made the findings discussed above, Mewett challenged this demoralized state of affairs and called on the province to restore the office of the justices. He wrote in insightful terms of the role justices of the peace play, and declared that without them the justice system "as we know it would collapse." 33 His report offered a battery of recommendations which addressed the two most serious deficits - a lack independence and professionalism - by proposing structural change. In the meantime, the justices lacked authority and institutional resources, and were powerless to address these issues on their own. It was therefore a matter of waiting for the legislature to undertake the far-reaching changes Mewett and others had identified as compelling, and even urgent in nature.

\section{Transformative change}

Through an incremental process of law reform, the justice of the peace's office has been all but transformed in the interval since the Mewett report. It is useful to begin by placing book ends around the starting and end points of this narrative, because the contrast could hardly be more striking. It would not be an exaggeration, nor would it be unfair, to describe the office, as Mewett found it in 1981, as backward in every way. Now it is the opposite: today, independence and professionalism are the hallmarks and defining features of Ontario’s justices of the peace.

\footnotetext{
${ }^{31}$ Ibid. at 33.

32 Doob report, supra note 15 , at 39 (the quote was in reference to justices of the peace in New Brunswick).

${ }^{33}$ Mewett report, supra note 2 , at 38.
} 
Legal institutions in Ontario have changed greatly in the last fifty years, but none perhaps as much as the system for justices of the peace. This transformation was achieved by wholesale change throughout the system, on qualifications and the appointments process; court administration; professional training and education; tenure and removal; and remuneration. The three key steps in the process were the statutory reforms of $1989 ;^{34}$ the development of a remuneration commission for justices of the peace $(1995 ; 1999) ;{ }^{35}$ and the comprehensive reforms introduced by the Access to Justice Act, 2006. ${ }^{36}$ These reforms cannot be placed in any hierarchy of importance but should be viewed collectively, because nothing short of an overhaul would have been able to fix the deep-seated problems of the system.

Starting with the office itself, the current statutory framework defines the lines of authority and procedures that regulate and professionalize the process of appointment. The 1989 legislation took an important first step in empowering the Justices of the Peace Review Council to consider all appointments and designations, and to make reports to the Attorney General. ${ }^{37}$ That said, the reforms that were necessary to professionalize the process more fully were not undertaken until the Access to Justice Act was passed in 2006. This legislation introduced

\footnotetext{
${ }^{34}$ An Act to revise the Justices of the Peace Act, S.O. 1989, c.46.

${ }^{35}$ The first commission on remuneration of justices of the peace, which made its report in 1995, was litigated; see Re Ontario Federation of Justices of the Peace Association v. Ontario (AG) (1999), 43 O.R. (3d) 541. In 1999 the legislation was amended to provide for the establishment of a Justice of the Peace Remuneration Commission, S.O. 1999, c.12, sched B, s.12(2). Report of the Second Ontario Justices of the Peace Commission, 2000, at 4 and 1. http://www.justice.gov.yk.ca/pdf/Tab 17 Report of 2000 Ontario Justices of the Peace Remuneration Com mission.pdf

${ }^{36}$ S.O. 2006 , c.21, schedule B, Amendments to the Justices of the Peace Act and the Public Authorities Protection Act.

${ }^{37}$ Section 9 of the 1989 legislation established the composition of the Council, as follows: the Chief Judges of the Provincial Court, Criminal and Family Divisions; the Co-ordinator; a justice of the peace; and no more than two other persons. Supra note 34.
} 
important provisions dealing, respectively, with the designation of justices of the peace, their qualifications, and the appointments process.

First, while the 1989 legislation followed Mewett's recommendation and adopted his proposal to designate justices as presiding or non-presiding, the 2006 statute abandoned the distinction and all justices of the peace are now appointed as presiding justices. ${ }^{38}$ What it means is that the lingering hierarchy between classes of justices is now discontinued and will be phased out over time, in favour of an office in which all justices are equal and authorized, without restriction in the terms of their appointment, to assume all duties. Second, while it allocated responsibility for appointments to a committee of professionals, the 1989 legislation did not set minimum qualifications for justices of the peace. In 1981, Mewett decided against pre-existing knowledge of the court system as a prerequisite for appointment, though he did recommend minimum education levels (grade XII), and the rudiments of a more rigorous process of appointment. ${ }^{39}$ Minimum qualifications for office were prescribed by statute for the first time in 2006, and now those seeking appointment as a justice of the peace must have a university education and ten years' experience in order to qualify. ${ }^{40}$ Again, it bears noting that the education and experience of those in office will be raised and equalized over time, as more appointments are made under this regime.

\footnotetext{
${ }^{38} 2006$ legislation, s.4(1). Supra note 36.

${ }^{39}$ Mewett report, supra, note 2, at 67-71 (explaining his recommendations on qualifications and the process of appointment).

${ }^{40} 2006$ legislation, supra note 36, s.2.1 (15)-(17) (prescribing these qualifications, as well as providing for equivalency programs and exceptional qualifications).
} 
Third, the 2006 statute also refined and developed the process around appointments by creating a Justices of the Peace Appointment Advisory Committee, institutionalizing its functions, and charging the committee with the responsibility to recruit, identify, classify, and recommend candidates for appointment. ${ }^{41}$ As a result of these initiatives, the process of appointment today is rigorous, transparent, and accountable. ${ }^{42}$ It bears no resemblance whatsoever to the practices of the past, and the systemic problems discussed in the Mewett report have been fully remedied.

The statutory amendments also addressed other elements of the justices' independence and professionalism. Access to training and education, which had been abysmal in the past, is an explicit objective of justice of the peace governance today. Under s.13 of the 2006 Act, the Associate Chief Justice Co-ordinator of Justices of the Peace has responsibility for standards of conduct for the justices. Among the goals s.13(3) identifies are "1. Recognizing the independence of justices of the peace," and "5. "emphasizing the need to ensure the on-going development of justices of the peace and the growth of their social awareness through continuing education". ${ }^{43}$ Ontario Court of Justice reports in 2005 and again in 2008-2009 provide detail about the content and structure of training and education for justices of the peace today. ${ }^{44}$

\footnotetext{
${ }^{41} \mathrm{Ibid}$. at s.21.1 (1)-(22) (prescribing the Committee's operations in close detail).

${ }^{42}$ For an example, see Annual Report of the Justices of the Peace Appointments Advisory Committee; September 2009-August 2010 (Toronto; August 2011) http://www.ontariocourts.ca/oci/files/annualreport/ipaac/2009-2010EN.pdf

${ }^{43} 2006$ legislation, supra note 36, s.13.

${ }^{44}$ See Ontario Court of Justice Annual Report 2005, at 63 (explaining the Senior Advisory Justice of the Peace and that individual's responsibility for planning, development, and implementation of education and training programs for justices of the peace): http://www.ontariocourts.ca/oci/files/annualreport/ocj/2005-EN.pdf; and Ontario Court of Justice Biennial Report, 2008-2009 at 59 (explaining the Advisory Committee on Education and the role it plays in ensuring that JPs receive the highest quality judicial education):

http://www.ontariocourts.ca/ocj/ocj/publications/biennial-report-2008-2009/
} 
As noted, security of tenure and the due process machinery of investigation and removal were key concerns of Mewett's. The 1989 legislation addressed these questions by prescribing a detailed process to be followed in cases of discipline or removal. ${ }^{45}$ That process was also modified and improved by the 2006 legislation, which created a complaints committee and prescribed a line of accountability in the process, which moves from the complaints committee to a hearing panel, and ultimately to the Attorney General. ${ }^{46}$ While the details are important, the central point for present purposes, once again, is that the lack of governance in the past has now been cured by the development of an institutional framework. Notably, the process has been structured to protect the public interest in the professionalism of its justices of the peace, and yet does so within a framework of due process that safeguards the security of tenure of justices and respects their judicial independence.

Summarizing to this point, the reform protocols on qualifications and appointment, training and education, tenure of office and removal significantly upgraded the justice of the peace's office. There is one more critical step to note in the process of reform, and this one took place at the administrative level. McRuer, the OLRC and Mewett were in agreement that the system was in a state of serious dysfunction. This, too, was addressed by the creation of the Ontario Court of Justice and the introduction of administrative structures to manage the orderly

\footnotetext{
See also the Justices of the Peace Education plan, Ontario Courts of Justice website: http://www.ontariocourts.ca/oci/iprc/education-plan/

$\frac{}{45} 1989$ legislation, supra note 34, ss. 8-12.

${ }^{46} 2006$ legislation, supra note 36, ss.10.2-11.2 (dealing with all aspects of complaint, investigation, hearing, report, and removal).
} 
assignment, supervision and monitoring of the justices. ${ }^{47}$ These measures made an enormous difference in providing organization, structure, and direction to the office and work of the justices of the peace.

To conclude this discussion, a couple of observations can be made about remuneration. In the past, justices of the peace were not only poorly paid, as Mewett and others have found, but the remuneration scheme was unprincipled and incoherent. This section has shown how demoralized and lacking in integrity the system was in 1981, when Mewett made his recommendations. His call for the restoration of the office was heeded, and though it has taken many years most of those recommendations have been implemented. The system of fee-forservice was abolished in 1995, and Ontario's justices of the peace today are salaried on a full, part-time or per diem basis. The patent unfairnesses of the old system have been corrected and remuneration commissions have been in place since 1995.

It is important to ensure that the remuneration for justices of the peace keeps pace with, and reflects, the transformations of recent years. Though the pace of change was incremental, the legislature has comprehensively addressed the systemic problems that compromised the independence and professionalism of Ontario's justices of the peace. The structures now in place create a statutory framework that rationalizes the office, treats the justices as judicial officers, and equips them to discharge their responsibilities. There cannot be any doubt that the office of the justices has been radically transformed for the better.

\footnotetext{
${ }^{47}$ The 1989 legislation created the office of "Co-ordinator of Justices of the Peace" and empowered the Coordinator to administer the justices of the peace, under the direction of the Chief Judges of the Provincial Court; supra note 34. Under s. 12 of the 2006 legislation, the "Associate Chief Justice Co-ordinator of Justices of the Peace" assumed this responsibility; supra note 36 .
} 
Since 2006, Ontario’s justices of the peace have been serving as full-fledged members of the judiciary whose terms of appointment, tenure, and administrative structures have been brought under a governance structure that introduced transparency and accountability into all aspects of the office. Moreover, though a law degree is not now a prerequisite for appointment, the gap in qualifications which was once so dramatic has narrowed as a result of the amendments. At present, $10 \%$ of Ontario’s justices of the peace are legally trained, and under the 2006 legislation justices will bring higher qualifications to the office over time, as those who lack those qualifications age and gradually become eligible for retirement. ${ }^{48}$

The transformation that took place between the 1981 Mewett report and the present could hardly have been more remarkable. Against the backdrop of these signal developments, it remains now to consider the work itself and ask how justices of the peace fit into the larger scheme of justice in the province.

\section{A context of justice}

It is important to understand the institutional design of the office - as described above because it is the setting in which Ontario's justices of the peace work today. In turning to their work, it can be noted that there are two ways to understand the role of the justices: while the first considers the jurisdiction they exercise from day to day, the second reflects on the functions of office from a more conceptual perspective. In doing so, that approach looks beyond the formal details of jurisdiction to consider the role justices of the peace play and how that role fits the

\footnotetext{
${ }^{48}$ Reported in Press Release, "New Orazietti Bill proposes Improvements to Ontario Justice System", May 31, 2012: http://www.saultstar.com/2012/05/31/new-orazietti-bill-proposes-improvements-to-ontario-justice-system
} 
overall scheme of justice in Ontario today. A holistic view of Ontario's justices of the peace - a context of justice, as it were - requires attention to both.

The details of justice of the peace jurisdiction are disparate, and it can be difficult to gain a sense of the office without a consolidated overview. Generally speaking, justices of the peace exercise jurisdiction that is at once specific and limited, and astonishingly broad at the same time. Their powers arise under federal as well as provincial legislation, and engage a wide range of statutes and tasks. On its face, the scope of jurisdiction is striking because it points to the diverse and extensive responsibilities that are entrusted to the justices under all manner of statutory instruments. Though the volume of work may be concentrated in particular areas, the justices must be prepared, through training and resources, to deal effectively and fairly with all matters falling in their jurisdiction.

For example, justices of the peace are empowered by the terms of the Contraventions Act to hear charges under certain federal statutes, including the Fisheries Act, Canada Shipping Act, Immigration and Refugee Protection Act, Motor Vehicle Transport Act, Indian Act, and Migratory Birds Act, among many others. Justices of the peace also handle a variety of tasks under the Criminal Code; they issue summonses and warrants for the arrest of the accused, deal with applications for publication bans, preside over matters involving adjournments and remands, and put the accused to their election on mode of trial. ${ }^{49}$ Another function that was

\footnotetext{
${ }^{49}$ Although authorized by the Criminal Code to do so, Ontario's justices of the peace do not conduct trials for summary conviction offences.
} 
traditionally important, and remains salient today, concerns the role justices of the peace play in receiving private informations under the Criminal Code, and conducting pre-enquête hearings. ${ }^{50}$

In addition, and more to the point, justices of the peace are the workhorses of the provincial regulatory system. Ontario’s justices enforce a wide array of more than 250 statutes, as well as countless municipal by-laws. ${ }^{51}$ Some of the issues which fall in their jurisdiction under the Provincial Offences Act ("POA") include motor vehicles (i.e., Highway Traffic Act, Compulsory Automobile Insurance Act), occupational health and safety (i.e., Occupational Health \& Safety Act, Workplace Safety and Insurance Act), environmental protection (i.e., Environmental Protection Act ), the regulation of controlled substances (i.e., Liquor Licence Act, Smoke-Free Ontario Act), safety regulation (i.e., Food Safety and Quality Act), consumer protection (i.e., Consumer Protection Act, Consumer Reporting Act), and public order (i.e., Trespass to Property Act, Safe Streets Act, Dog Owner's Liability Act). In addition to hearing charges and adjudicating offences, justices of the peace issue warrants under Christopher's Law and the Child and Family Services Act, and make orders for medical examinations under the Mental Health Act.

In any year and by any measure, the volume of work that arises under the POA is immense. Though the information is dated, Strathy J. stated in 2008 that in an average year Ontario justices of the peace will deal with more than 1,700,000 charges under the POA. ${ }^{52}$ More recently, the Law Commission of Ontario’s ("LCO”) Final Report, Modernization of the

\footnotetext{
${ }^{50}$ In 1991, the Doob report stated that "[r]eceiving and acting on private informations can be a difficult judicial task and it can emphasize all that is 'judicial' in the role of the justice". Supra note 15, at 20. For a summary of the preenquête process see Morton's Musings: http://jmortonmusings.blogspot.ca/2011/05/pre-enquete-hearings.html

${ }^{51}$ Ontario Court of Justice Biennial Report, 2008-2009, supra note 44, at 59.

${ }^{52}$ Association of Justices of the Peace of Ontario v. Ontario (AG), [2008] O.J. No. 2131, at para. 11.
} 
Provincial Offences Act” analyzed the work by volume and offence; in 2011, it reported that "approximately 2 million charges were laid in Ontario over each of the past three years under offence-creating statutes to which the POA applies”. ${ }^{53}$ Under any view of the numbers, it is clear that the efficiency, integrity, and legitimacy of provincial regulation rest on justices of the peace. The statutes they enforce set standards for the health, safety and protection of Ontario residents, and it is vitally in the public interest that the system be adequately resourced and effectively administered.

In the words of the LCO, "[r]egulatory law dominates many aspects of our daily living”, and the POA has a significant impact on the lives of Ontarians, "not merely because of the vast number of offences to which the POA applies or the number of proceedings commenced each year, but because of the nature of the regulatory offences governed by its process”. ${ }^{44}$ These laws are "necessary to regulate and reduce the risk we impose on each other through activities as diverse as driving a car, operating a school, spraying a herbicide or constructing a nuclear power plant”. ${ }^{55}$ This regulatory framework, comprising a large number of diverse statutes, is at the core of the provincial government's mandate and responsibility to enact and enforce laws which advance and protect the public welfare, broadly understood.

The Law Commission's report was undertaken because the "provincial offences environment has changed considerably” and yet there have been only modest amendments to the

\footnotetext{
${ }^{53}$ See Modernization of the Provincial Offences Act", Final Report, Law Commission of Ontario, August 2011 ("POA report") at 14 \& 24 (reviewing the Provincial Offences Act and making recommendations for law reform). Available online: http://www.lco-cdo.org/en/provincial-offences-final-report

${ }_{55}^{5} \mathrm{lbid}$. at 8.

${ }^{55}$ Ibid. (quoting John Swaigen).
} 
$P O A$ since it was enacted, more than thirty years ago. ${ }^{56}$ The LCO's catalogue of changes includes these items: the adoption of the Charter, amendments to the Criminal Code, significantly increased maximum penalties for certain provincial offences, the increased use of administrative monetary penalties (AMPS), the emergence of licensed paralegals, and the increased use of technology. ${ }^{57}$ In advancing many recommendations for reform, the Commission remarked that "[t]oday, respect for the administration of justice, speed, efficiency and a convenient or simple process remain laudable goals for a procedure that governs the adjudication of minor offences", and added that "[t]]hese are particularly important objectives where the vast majority of defendants are self-represented". ${ }^{58}$ Though the LCO's analysis of these changes was directed at its recommendations for reform, its analysis provides insight into the impact of change on the work of the justices in managing and enforcing this vast network of regulation.

Justices of the peace also have primary and almost exclusive responsibility for the administration of criminal justice in two critical areas: search warrants and bail hearings. Search warrants are the engine of the investigative process and are highly regulated by the Criminal Code provisions and the case law, including Supreme Court of Canada jurisprudence under s.8 of the Charter of Rights and Freedoms. ${ }^{59}$ To protect the integrity of investigations, the warrant process must be ex parte in nature. In reviewing applications and issuing warrants, justices of the peace therefore must have a strong command of the technical details of the law, which is in a

\footnotetext{
${ }^{56} \mathrm{Ibid}$.

${ }^{57} \mathrm{lbid}$. See also the discussion, "Key Developments that Support Reform at This Time", ibid. at 1-13 (explaining the Commission's view of the key changes that have taken place in the years since the POA's enactment).

${ }^{58}$ Ibid. at 15.

${ }^{59}$ Section 8 states that "[e]veryone has the right to be secure against unreasonable search or seizure". The Canadian Charter of Rights and Freedoms, Part 1 of the Constitution Act, 1982, being Schedule B to the Canada Act 1982 (UK), 1982, c.11.
} 
constant process of change, both by legislative amendment and judicial interpretation. The justices must understand the demands of the investigative process but also exercise vigilance on behalf of the subject of search, who is not present and unable, therefore, to defend the privacy interests at stake that are constitutionally protected by s.8.

This task engages critical values on both sides - law enforcement on one and the expectation of privacy and freedom from unreasonable intrusion from the state on the other. In the circumstances of ex parte proceedings, transparency and accountability only come into play after the fact, when search warrants have been executed. That points up the need for justices to take great care initially in considering and authorizing searches that will unavoidably infringe privacy rights. Evidence that is illegally obtained can be excluded at trial, if and when the circumstances surrounding the application for a warrant or its execution are challenged by the accused. ${ }^{60}$ In addition, applications for access to warrant material may be made and appear to be becoming more common, as investigative journalists seek information about police activities and the targets of their investigations. Though the media's primary interest is in who the police are interested in and why, the process also comes to light and can become a matter of public interest and debate. In brief, then, these are some of the reasons why responsibility for search warrants is a critical element of the justices' work. $^{61}$

\footnotetext{
${ }^{60}$ For a recent example of evidence excluded because the warrant was improperly granted, see http://www.thestar.com/news/crime/2013/06/10/botched case highlights need for jps to have legal training .html

${ }^{61}$ See the Cory Commission, supra note 1 at 5 (making the point that this work is "vitally important", and noting that " $[\mathrm{w}]$ ith the advent of the telephone search warrant, Justices of the Peace must, at all hours if the day and night, consider urgent applications for search warrants").
} 
Even so, bail hearings may be the most challenging part of the justices' work today. Although this short discussion focuses on bail under the Criminal Code, it can be noted in passing that - albeit less frequently - the justices are also responsible for bail hearings under the POA. ${ }^{62}$ Hearings under the Code are conducted in open court, albeit pursuant to a publication ban, and under a requirement that those detained be presented before a justice within 24 hours. This timeline creates obvious pressures, especially in cases of mass arrests, which place demands on the availability of courtrooms and justices of the peace. Bail hearings are important because they may constitute an offender's first interface with the court system, in circumstances where the outcome will be either that the accused will be detained in prison or released to the community. ${ }^{63}$ Although the right to bail is guaranteed by s.11(e) of the Charter, the issues that arise at these hearings are far from straightforward and bail is not a simple matter. ${ }^{64}$

The constitutional right not to be denied bail is subject to statutory exceptions that have been upheld under the Charter. These exceptions allow the Crown to "show cause" and demonstrate why it is justifiable to deny bail and detain an accused instead. The process can be complicated by reverse onus provisions, which in some instances shift the burden from the Crown and ask or invite the accused to "show cause" why he or she should be released. In addition, the Charter right is qualified under s.11(e) by the language of "reasonable bail”, which introduces the question of conditional release - restrictions on an accused's release as a condition

\footnotetext{
62 Final Report on the POA, supra note 53, at 100-06 (addressing bail under the provincial regime).

${ }^{63}$ See Toronto Star Newspapers Ltd. v. Canada, [2010] 1 S.C.R. 721 (stating, at para. 51, that "[a] day in the life of an accused person may have a lifelong impact", and declaring, as well, that where the potential for a loss of freedom exists for even a day society must place the "highest emphasis" on minimizing the chance of an unwarranted denial of liberty"; emphasis added).

${ }^{64}$ Section 11 states that "[a]ny person charged with an offence has the right ... (e) not to be denied reasonable bail without just cause". See generally, S. Penney, V. Rondinelli \& J. Stribopoulos, Criminal Procedure in Canada (Toronto: LexisNexis Canada, 2011), chapter 6 on Bail, 363-416.
} 
of bail - and whether such restrictions are reasonable. Starting from a presumption of bail without limits or unconditional release, justices of the peace are required to determine where to place an accused on the "ladder" of conditions that are increasingly restrictive of liberty. Here, the justices have considerable discretion in balancing the public interest in preventing flight and protecting the community from risk, against the right of the accused to be presumed innocent and granted as much liberty as is reasonable, in the circumstances. ${ }^{65}$

This brief summary demonstrates that the bail decision is an adjudicative function of crucial importance. Those charged with offences are entitled to be presumed innocent pending trial, and to benefit from the presumption in favour of reasonable bail. Denying bail or attaching restrictive conditions engage the Charter rights of the accused. At the same time, the community has a strong stake in proceedings which can be highly controversial, especially in cases where violent crimes which generate fear, revulsion and strong emotion have been committed. All this to say that the bail system places heavy demands on the criminal justice system, ones that are difficult to satisfy. It is at the core of the system, not only because the outcomes of proceedings are so closely watched - although the details are protected by publication bans - but also because the system must balance the argument for detention against the presumption in favour of bail. In doing so, the decision whether to grant bail implicates access to justice values and raises basic questions about what justice means. For these reasons, the bail system is a frequent subject of study and critical comment. ${ }^{66}$

\footnotetext{
${ }^{65}$ Surety is another important element of the bail system, which generates a host of its own issues, which include the decision to require a surety, to approve the accused's nominee, and to settle the terms and conditions of the surety.

${ }^{66}$ See, e.g., "Reasonable Bail", John Howard Society of Ontario, released September 2013 (recently released report which states, and then explains, that "[w]e have a bail problem in Ontario");
} 
The criminal justice system in Ontario has changed dramatically since the Mewett report was written in 1981, one year before the introduction of the Charter. It is obvious to all how much the Charter's legal rights and equality guarantees, among others, have transformed the criminal law in the last thirty years. The justices of the peace and the corners of the Criminal Code they administer are no exception. Yet the Charter is not the only source of change; as the LCO noted, the provincial regulatory framework has become much more complex in recent years, and the same can be said of the Criminal Code. The criminal law continues to be amended, and interpreted by the appellate courts on issues of statutory interpretation as well as on questions arising under the Charter. LeSage and Code have written of these changes in the particular context of large and complex trials. ${ }^{67}$ In that setting they observed that "[w]e therefore begin with the realization that the criminal trial will never be what it was in the 1970s. We are operating today in a very different legal context."68 Though the justices do not face the same challenges, they are not immune from the cluster of changes, pressures, and demands that have affected the courts systemically in recent years. ${ }^{69}$

http://www.johnhoward.on.ca/pdfs/Reasonable\%20Bail\%20-\%20JHSO\%20Report\%202013\%20final.pdf. See also J. Sprott \& N. Myers, "Set Up to Fail: The Unintended Consequences of Multiple Bail Conditions" (October 2011) Canadian Journal of Criminology \& Criminal Justice, 404-21 (considering the impact of bail conditions on youth offenders); C. Webster, "Out of Sight, Out of Mind: A Case Study of Bail Efficiency in an Ontario Video Remand Court" (2009-2010), 21 Current Issues in Criminal Justice 103-26 (discussing problems with video remand); and N. Myers \& S, Dhillon, "The Criminal Offence of Entering any Shoppers Drug Mart in Ontario: Criminalizing Ordinary Behaviour with Youth Bail Conditions" (2013) 55(2) Canadian Journal of Criminology \& Criminal Justice 187-214 (criticizing the bail conditions imposed on youth).

${ }^{67}$ See generally The Hon. P. LeSage \& M. Code, Report of the Review of Large and Complex Criminal Case Procedures (Ontario: Queen's Printer, 2008).

${ }^{68}$ Ibid. at 14 (emphasis added).

${ }^{69}$ Other changes have been brought to light in the AJPO's preparation for the work of this commission. See M. Kleiman, B. Ostrom, J. Hann, C. Lee, \& S. Roth, Workload Assessment Update, Ontario Justices of the Peace; September 2013 (identifying a variety of new elements and pressures in the work of the justices since 2008). 
The parameters of jurisdiction surveyed also invite broader reflection or comment on the "office" of the justices and their role in the system. The Mewett report (1981) and Doob report (1991) gave this question significant attention, though the focus since then has been on practical realities and the details of office, as recounted to this point (i.e., matters of structure and design; scope of jurisdiction; workload). Yet it is just as true today as it was when Mewett wrote it: without justices of the peace the criminal justice system would collapse ${ }^{70}$ Despite that reality and the likelihood the justices may be more indispensable today than before - being set apart and for a long time treated as a subordinate part of the system is part of their narrative. That is the essential ambivalence of their history: to be respected and yet set apart, at the same time, for being different, or singular. Lingering negative perceptions from the past cannot be fully set aside, once and for all, without first being brought into the open and acknowledged.

Mewett and Doob clearly valued the distinctive role lay justices play in our justice system. Citing a host of examples from a checklist of their functions, the Mewett report lauded justices of the peace as "the first line of defence against abuse of process," and identified the justices as "in fact the original, and still essential, ombudsman". ${ }^{71}$ The report also warned that if the office were to be abolished or even "demeaned or reduced in function, directly or indirectly", the result would be that "these safeguards and rights of the citizen [will] inevitably [be] made less secure”. ${ }^{72}$ Nor did it discount their role or contribution because of their status as lay justices. To the contrary, the report accepted that justices of the peace are "judicial officers in every sense

\footnotetext{
${ }^{70}$ Supra note 33.

${ }_{72}^{71}$ Mewett report, supra note 2, at 55.

${ }^{72}$ Ibid.
} 
of the word" and spoke of the justices as "judges and protectors of the individual”. ${ }^{73}$ Mewett called for justices of the peace to be “capable, independent and fearless” in the performance of duties and exercise of office, and made recommendations that showed what was required for that to happen. ${ }^{74}$ In addition, he cautioned against drawing comparisons between justices of the peace and judges that are based on differences in training. Professor Mewett spoke against comparing the relative importance of JPs and other judges and said, instead, that " $[t]$ hey are both equally, if differently, important in the criminal justice system". ${ }^{75}$ In his view the salary of a justice of the peace should be "at a level that reflects his importance and prestige”. ${ }^{76}$

Ten years later, the Doob report conducted social science research to learn more about Canada's justices of the peace, and in doing so canvassed the justices from several provinces including Ontario - on virtually all issues addressed by Mewett. ${ }^{77}$ The gist of this report is best summarized in the words of its authors, and that is "taking justices seriously."78 Though the report is nearly twenty-five years in the past, it offers insights which linger to this day, and for that reason should not be forgotten. What emerges from the Doob report is a conception of role that shows why lay justices are a valuable and distinctive feature of the system. It speaks to the "bewildering variety of roles" undertaken by justices of the peace, ${ }^{79}$ and describes these functions in the words of the justices, who referred to themselves - variously and candidly - as a “buffer, facilitator, rubber stamp, protector of the public interest," and also described themselves

\footnotetext{
73 lbid. at 57 \& 55 .

${ }^{74}$ Ibid. at 56 .

${ }^{75}$ Ibid. at 88 (emphasis added).

${ }^{76}$ Ibid. at 41.

${ }^{77}$ The report also canvassed justices of the peace from British Columbia, Manitoba, Quebec, as well as New Brunswick and the Yukon. Doob report, supra note 15.

${ }^{78}$ Ibid. at 251-52.

${ }^{79}$ Ibid. at 84.
} 
as executive assistant to justice, handmaiden to the police, the sponge of trivia from court dockets, and independent judicial officer. ${ }^{80}$ The justices commented on their function as a “middleman”, "buffer" and "barrier” between an "overactive policeman, and a member of the public; they spoke of the need for JPs "to ensure that the rights of people are protected as well as the rights of the public as a whole". ${ }^{81}$ As one justice put it, quite insightfully: "I am totally independent ... In essence, a JP represents twelve good men [sic] in truth - the jury”. ${ }^{2}$ The same justice continued by adding, along similar lines, that, unlike judges, the justices are able to look at questions “more from a citizen’s point of view."83

The Mewett and Doob reports both also spoke of the ways justices of the peace had been neglected or poorly treated. The Doob report took the pulse of the justices and in doing so validated many of their concerns: the office was perceived as one of low status; the justices were poorly paid; and they experienced a lack of respect across the spectrum, which in turn reinforced their position in the system. Through questionnaires they spoke of feeling undermined or devalued because they are considered to be lay justices and generally are not legally trained. ${ }^{84}$ As the Doob report explained, the "apparent low status" of justices of the peace affected other aspects of their jobs, such as being poorly paid, not given adequate offices, and generally being treated in a manner that would not be considered appropriate for other judicial officers. ${ }^{85}$

\footnotetext{
${ }^{80} \mathrm{Ibid}$. at 41.

${ }^{81} \mathrm{lbid}$. at 28.

${ }^{82} \mathrm{Ibid}$. at 24.

${ }^{83}$ Ibid.

${ }^{84}$ Ibid. at 250.

${ }^{85} \mathrm{Ibid}$. at 250.
} 
It is obvious, and important, to note that that was then and this is now. Today, the justices of the peace remain unique in the system because in Ontario they serve, for the most part, as lay justices, and undertake their responsibilities under a series of mandates that are vast but delineated by statute. For that reason many of their functions are singular, and are not replicated elsewhere in the system. By virtue of their functions, the justices are in the front lines and are connected to the community in ways that are not possible for other judicial officers. At the same time, the office has been transformed, and Ontario’s justices of the peace have been brought into closer alignment with other members of the judiciary. They are more like others and yet remain different. Even so, the justices have retained what is distinctive and valuable in their role, and the dysfunctional elements of the office - which had more to do with the administration of the office than anything the justices controlled - have been ameliorated.

Not unexpectedly, it may take time for attitudes to catch up with changes to the office. While the 2006 reforms are relatively recent, perceptions and impressions of the justices, in the broader public as well as in the legal profession, may be deep-seated. It bears emphasizing that these reforms were pushing back against a history of neglect which, according to Mewett, was 100 years in the making. In 1981, he called for the office of the justices of the peace to be restored and the justices to be accorded the respect they deserve. It is not so much a question of equating justices of the peace with others as it is of recognizing them, in Mewett's words, as “equally, if differently, important”. For that to happen, any lingering perceptions of the justices as low-status judges must explicitly and definitively be placed in the past, once and for all.

\section{Conclusion}


In words that have been cited many times, Strathy J. made the following observations about Ontario's justices of the peace in 2008. He noted the progress that had been made in reforming the office, and stated that "the qualifications of the bench have been enhanced, the tenure of the justices have been made more secure and the processes and procedures surrounding the office have been made more professional, more formal and, in a word, more 'judicial”, ${ }^{86}$ He went on to comment that this evolution reflects the important role the justices play in the administration of justice in Ontario and the significance the legislature attaches to that role. To him, these were fundamental, and evinced a desire on the part of the province to attract highly qualified applicants and to provide a structure, within the framework of judicial independence, to support the performance of the justices’ responsibilities. ${ }^{87}$

Ontario’s justices of the peace have come a long way since 1981 and the Mewett report. In the circumstances, statutory reform was imperative, and the province should be commended for taking the steps that were needed to overhaul the system. At the same time, two other developments which are closely related are just as critical and should not be understated. The first concerns the evolution of judicial independence and the recognition that justices of the peace are members of the judiciary, and included as such in the scope of the constitutional concept of judicial independence. ${ }^{88}$ If it seems obvious, any review of the Mewett report would show how pivotal a step it was to interpret the principle inclusively, thereby recognizing the

\footnotetext{
${ }^{86}$ Supra note 52 , at para. 32.

${ }^{87}$ Ibid.

${ }^{88}$ See Reference re: Remuneration of Judges, [1997] 3 S.C.R. 3 (creating and establishing judicial independence as an unwritten constitutional principle, and requiring independent commissions to address the question of remuneration).
} 
judicial status of the justices and the need to protect their independence. ${ }^{89}$ The second is the establishment of remuneration commissions for the justices, as for other members of the provincial judiciary, and the institutionalization of a process to ensure that their circumstances are openly and fairly assessed at regular intervals. That, as well, was a step of immense significance in the evolution of the office. No single step on its own would have been enough to bring independence and professionalism to the office of the justice of the peace but, taken together, the three in combination brought about a remarkable transformation.

As indicated at the outset, the purpose of this paper has been to retrace the history of the justices, from the Mewett report to the present. In doing so, it situates the justices in 1981, before reforms were undertaken, and then shows how profoundly the office has been transformed. The hope, in tracing that history, is that it can provide a "context of justice" for understanding Ontario’s justices of the peace and their role in the justice system.

\footnotetext{
${ }^{89}$ Note, though, that “...judicial independence does not require that all judges of all courts be treated in identical fashion or that the provisions in respect of their tenure be the same. Variations are appropriate to reflect differences in their functions and responsibilities." Ell v. Alberta, supra note 1, at para. 72.
} 


\section{Appendix}

\section{Jamie Cameron}

Professor Jamie Cameron has been a full-time member of the faculty at Osgoode Hall Law School since 1984. She holds law degrees from McGill University and Columbia University, clerked at the Supreme Court of Canada for the Hon. Justice Brian Dickson, and was on the faculty at Cornell Law School before joining Osgoode.

Today, Professor Cameron is one of Canada's senior constitutional scholars, whose research and teaching interests focus on the Charter of Rights and Freedoms, freedom of expression and the press, the Supreme Court of Canada, criminal law, American constitutional law, and judicial biography. She is a past editor-in-chief of Osgoode Hall Law Journal, and a coguest editor of two special issues (2013) and (2014, forthcoming). She has written extensively in these areas and has been the editor and co-editor of a dozen book collections, including the annual Constitutional Cases volumes, The Charter's Impact on the Criminal Justice System, Reflections on the Legacy of Justice Bertha Wilson, and The Charter and Criminal Justice: Twenty-Five Years Later. She has chaired and co-chaired many conferences and events, which include Osgoode Hall's Annual Constitutional Cases conference $\left(17^{\text {th }}\right.$ in 2014); a $25^{\text {th }}$ anniversary conference on the Charter and criminal justice (2007); In the Public Interest: The Law and Ethics of Investigative Journalism (2011); Rights Constitutionalism and the Canadian Charter of Rights and Freedoms (2012); a symposium in honour of Professor John McCamus (2013); and Part XX.1 of the Criminal Code: Not Criminally Responsible and Lessons from Bill C-54 (fall 2013).

She has been a Director and Vice-President of the Canadian Civil Liberties Association for twenty years, and for ten years served on the Board of Directors for the BC Civil Liberties Association. She has represented the CCLA in cases at the Supreme Court of Canada. In 2012, Professor Cameron completed a six-year term on the Academic Freedom \& Tenure Committee of CAUT, and was recently appointed a Director of the Harry Crowe Foundation. She was on the Board of Trustees of the McMichael Canadian Art Collection from 2004-2012, and served as vice-chair of the McMichael from 2011-2013. In addition to the CCLA and the Harry Crowe Foundation, she is currently a member of the Ontario Review Board and sits on the Board of Directors for Canada’s National Ballet School.

October 2013 